\title{
Comparative Evaluation of Three Sugarcane Supply Strategies in Colombia: Logistics, Energy and GHG Emissions
}

\author{
J. A. Lozano ${ }^{1 *}$, M. K. Delivand ${ }^{2}$ and F. Maréchal ${ }^{3}$ \\ ${ }^{1}$ Universidad Autónoma de Occidente, GICPE, Cali - Colombia \\ ${ }^{2}$ University of Applied Science (HTW), Regenerative Energien, Berlin - Germany \\ ${ }^{3}$ Ecole Polytechnique Fédérale de Lausanne, IPESE, Lausanne - Switzerland \\ E-mail: jlozano@uao.edu.co
}

Received 27 October 2014, Accepted 06 July 2015

\begin{abstract}
Sugarcane-based ethanol in Colombia has a prospective opportunity to explore the production of ethanol from lignocellulosic biomass taking into account that a large amount of generated residues (between 50 and 100 t/ha) are left on the field after green harvesting. The use of sugarcane green harvesting residues for ethanol production could be considered as a feasible solution but it is facing high supply costs. A bottom-up engineering cost model was used to estimate the green harvesting residues supply cost for three collection strategies. The model took into account the investment and operation costs of the residues collection, processing, delivery, and machineries including depreciations, repair and maintenance, and labor cost. Overall energy consumptions and life-cycle GHG emissions of the three strategies were analyzed. The integral harvesting showed the best performance in costs (6.01 USD/dry- $t)$, energy consumptions (125.32 MJ/dry-t), and GHG emissions $(7.74 \mathrm{~kg} \mathrm{CO}$-eq/dry-t), followed by the baled and chopped residues.
\end{abstract}

\section{Keywords: Green harvesting residues; lignocellulosic ethanol; logistics; sugarcane residues; supply chain.}

\section{Introduction}

One of the leading options for fossil-fuel substitutes, which have recently received substantial interests all over the world, is the bioethanol. In Colombia, since 2001, the use of bioethanol has been prompted but it was only in the late 2005 that bioethanol production started in the Cauca river valley. Currently, the use of E10 (fuel blending of $10 \%$ bioethanol and $90 \%$ gasoline) is mandatory in the cities with population over 500 thousand inhabitants. Furthermore, the Colombian Decree 1135 started on January 2012 would require the use of E85 for the new vehicles with motors up to $2000 \mathrm{~cm}^{3}$ of capacity. The lower net GHG reduction, and land requirement and its competition with food products could be limits to the first ethanol production [1-4]. While the use of the agricultural residues for energy could be an advantage over the energy crops, in general, the high logistics cost is known to be one of the drawbacks in the use of agriculturalbased residues for energy purposes [5-7]. Governments will usually allocate subsidies or incentives to enhance the energy security and compensate for the higher production costs of biofuel in comparison to fossil-fuel [7].

Sugar industry is an established sector in Colombia [8$10]$. The country has approximately 223.905 hectares of land under sugarcane cultivation as of year 2012 (http://www.asocana.org). After sugarcane harvesting, considerable amount of about 50-100 t/ha of the lignocellulosic Green Harvesting Residues (GHR) are left on the field $[11,12]$. The variation relies on several factors such as types of harvesting (manual or mechanical), burning practices, topping heights, cane varieties, age of crops, and climate and soil characteristics [12]. Since 1996, burning of GHR has been phased out in the country leaving it a potential reserve for lignocellulosic ethanol productions.

While, there are various theoretical approaches and case study applications of the biomass supply chain modeling in the literature [5,13-16], few studies have addressed the logistics of sugarcane GHR. Michelazzo and Braunbeck [17] analyzed six collection scenarios of sugarcane GHR in Brazil. They found out that handling the whole stalk (integral harvesting) had the lowest cost, followed by the bulk handling of chopped GHR, the round bale, the cotton bale, and finally the pellet and briquette options. Ripoli and Ripoli [18] have also reported a lower delivery cost of GHR using the integral harvesting system instead of baling or transporting of the bulk chopped residues. In Colombia, Briceño and Cock [19] concluded a lower cost for the baled GHR as compared to bulk transportation of chopped GHR. The cost of GHR supply chain is estimated by considering several critical assumptions such as the moisture content, and machinery efficiencies [20].

In order to increase the current capacity of biofuel in Colombia, the implementation of the second generation bioethanol technology from agricultural-based biomass could be a key factor. Nonetheless, due to the GHR scattered distribution and low bulk density, it is necessary to evaluate the biomass logistics options based on the country's resources and practices. 


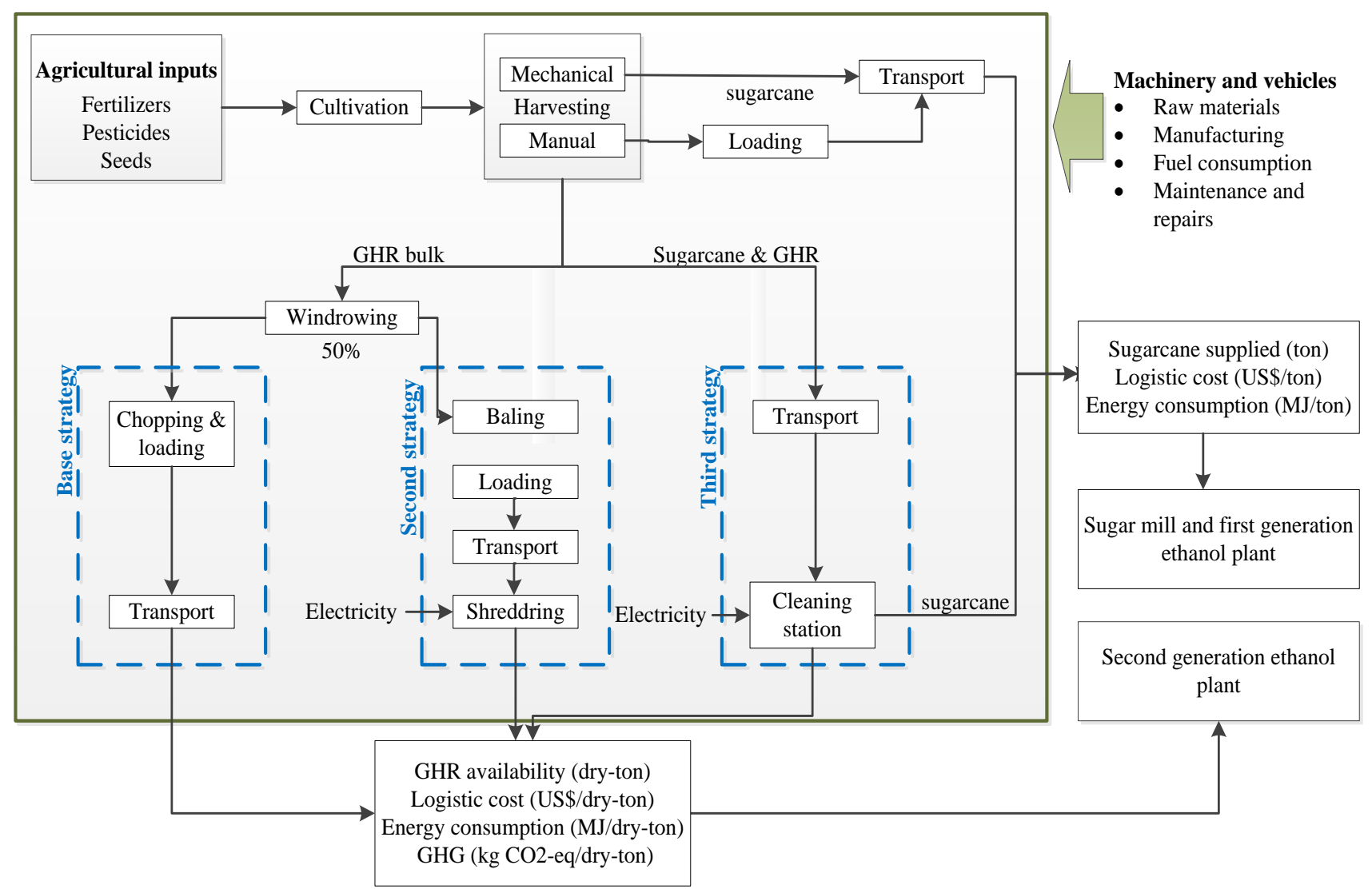

Figure 1. Logistics strategies for GHR supply.

In other words, a sustainable management and development of a whole new infrastructure for harvesting, transporting, storing and refining of the biomass is required. This study aims at contributing to this urge and has suggested three possible supply-chain strategies for sugarcane GHR in Colombia. The fuel delivery cost, the energy consumption and the life cycle GHG emissions for the strategies are also estimated.

\section{Methodology}

The delivery of GHR to a projected bioethanol plant could be complex due to the low energy density, high moisture content and dispersed characteristics of the fuel which make it economically not feasible on long-distance travel $[20,21]$. Sugarcane GHR can be used as a potential feedstock for the second ethanol production and hence, hit the ethanol market in Colombia to meet the blending biofuel regulations set by the government.

Three logistics strategies are selected for the analysis of costs and energy consumptions of supplying GHR in Colombia. Figure 1 shows the system boundaries including the current sugarcane logistics and the three strategies analyzed for the GHR supply. The objectives are to analyze: the total supply costs, direct energy consumption due to the transportation and the treatment of feedstock; indirect energy consumptions of agricultural machineries including the embodied energy of raw material manufacturing (steel and tires) and maintenance and repairs of machines; and GHG emissions of the operations involved in the three strategies. The labor and machinery cost was calculated for each operation. It is important to leave some proportion of the residues in the field for soil regeneration. There is no conclusive study on the proportion of the GHR to be left in the field for the soil maintenance; based on a literature survey
[2, 22-24], this proportion is $50 \%$ of GHR, which is considered in this study as well.

In the base strategy, after harvesting the sugarcane, cane is transported to the mill, and the GHR is left in the field. The GHR is windrowed; $50 \%$ of it is recycled for the soil protection, and remaining is collected, chopped (90\% efficiency) [20], and loaded into the wagons. In the second strategy, the windrowed GHR is baled, transported and treated before feeding in the plant. Rectangular bales of $0.8 \times 0.8 \times 1.9$ meters are considered, and baler efficiency is $84 \%$, heavy trucks with attached stacking unit (Stinger Stacker model 6500) carry the bales. In the plant gate, a bale handler is used for unloading, stacking, feeding the processor (shredder). In the third strategy (integral harvesting), the cane and GHR are transported together to the sugar mill. The cleaning system of the harvester has two extractors to remove the GHR; the primary extractor has a speed control, while the secondary extractor has only the on/off switch. Lowering the primary extractor speed increases the load of GHR into the wagon. The GHR and cane separation process takes place in a dry-cleaning station installed next to the mill operating 350 days per year, 24 hours per day. It has an installed capacity of 250 ton per hour and a power consumption of $228 \mathrm{kWh}$. The efficiency of the cleaning system is $70 \%$, and one operator is required for the shredder [24].

The transportation loss is assumed to be $2 \%$ for all strategies. The whole cycle of sugarcane cultivation and harvesting consists of 67 months including 15 months cultivation, and four subsequent 13-month-harvest periods (ratoon). The sugarcane is harvested either manually or mechanically. Currently, approximately $70 \%$ of the fields are manually harvested with an average rate of work of 3 tons per day. Mechanical harvesting has an average rate of work of 250 tons per day. The composition of the GHR in the field 
is approximately: $75-82 \%$ of damaged cane, $7-12 \%$ of dry leaves, $2-3 \%$ of green leaves and $7 \%$ stumps. There is a large variation in the moisture content after harvesting from $11.9 \%$ in dry leaves up to $78.6 \%$ in the stumps. However, in the absence of rain, the residues could reach an average moisture level of $40 \%$ in one week due to their natural drying rate (3$4 \%$ per day) [19]. The sugar cane variety CC $85-92$ is considered as it is currently cultivated on $71.5 \%$ of the area [25]. This variety has a cane and GHR yield of 117 and 45 ton per hectare, respectively [11]. The collection efficiency, machinery rates, and the moisture content of GHR have been taken into consideration to estimate the available GHR dryton at plant gate. The collection efficiency is defined as the ratio of the actual mass collected to the available mass that can be collected. The machinery rate of work is the theoretical machinery capacity multiplied by the machinery efficiency [26].

The main objective of this study is to measure the GHR availability, logistics costs, energy consumptions and the life cycle GHG emissions of the three strategies shown in Figure 1. The analysis also takes into account the current sugarcane supply system in order to offer a base assessment for the GHR strategies.

\subsection{Supply Cost}

The estimated global production costs of the secondgeneration bioethanol in literature currently range from 0.43 to 1.30 USD per liter [27-29].The feedstock cost constitutes around $35-70 \%$ of the total ethanol production cost, which is directly influenced by the logistics efficiency [30].

For a working life time of $4200 \mathrm{~h} /$ year (350 days and 12 hours per day), the logistic cost is estimated based on the methodology of ASAE standards EP496.2 and D497.4, [26] and [22]. Logistic costs are divided into two categories: Fixed and variable costs. Fixed costs are those that occur regardless of machine use. They include the ownership cost, $K_{o}$, in Eq. (1); and taxes, insurance and storage cost, $K_{t}$, in Eq. (2).

$$
K_{o}=P\left[\frac{i(1+i)^{y}}{(1+i)^{y}-1}\right]
$$

$K_{t}=P \cdot 0.02$

Where $\mathrm{P}$ is the purchase price in USD (Table 1); the lifetime (y) for agricultural machinery and vehicles is 5 and 10 years correspondingly; and the discount rate (i) is $10 \%$ [6]. The taxes, insurances and storage costs were assumed to be $2 \%$ of the purchase price [22].

Table 1. Input Data for Agricultural Machinery.

\begin{tabular}{lccc}
\hline & $P(\mathrm{US} \$)$ & $e_{\text {diesel }}(\mathrm{l} / \mathrm{h})$ & $R o W(\mathrm{t} / \mathrm{h})$ \\
\hline Harvester & $341^{\prime} 589$ & 39.75 & 25.00 \\
Loaders & $34^{\prime} 431$ & 7 & 87.10 \\
Wagons & $16^{\prime} 000$ & - & - \\
Tractor 105 HP & $82^{\prime} 079$ & 39.26 & - \\
Tractor 31 HP & $14^{\prime} 502$ & 11.64 & - \\
Windrower & $5^{\prime} 141$ & - & 199.32 \\
Chopper & $250^{\prime} 000$ & 59.52 & 30.20 \\
Rectangular & $57^{\prime} 258$ & - & 9.10 \\
baler & & & \\
\hline
\end{tabular}

The variable costs are mainly the cost for operating the machinery/vehicle. They vary directly with the use and rate of work of machineries/vehicles, and include: Repairs and maintenance, fuel and lubricant cost. The total variable cost is the sum of all the elements considered in this section. The following equations are used to calculate the repair and maintenance cost in Eq. (3), fuel cost in Eq. (4) and lubricant cost in Eq. (5) for the agricultural operations (USD/t).

$$
\begin{aligned}
& C_{R \& M-a g r}=\frac{T A R}{h \cdot y \cdot R o W} \\
& C_{f-\text { agr }}=\frac{e_{\text {diesel }} \cdot d c}{R o W} \\
& C_{l-a g r}=0.15 \cdot C_{f-a g r}
\end{aligned}
$$

The Total Accumulated Repair (TAR) factor represents the accumulated repair and maintenance cost in the life of a piece of equipment according to the machinery purchase price and are taken from [31] in Table 2. The symbols $h$ and RoW are the annual working hours and the machinery rate of work $(\mathrm{t} / \mathrm{h})$, respectively. $e_{\text {diesel }}$ is the diesel consumption in liters per hour (Table 1), and dc is the fuel cost in USD per liter. The agricultural lubricant cost is assumed to be as $15 \%$ of fuel cost [22].

Table 2. Total Accumulated Repair Factors (TAR) and Manufacturing Energy Coefficients $\left(e_{W}\right)$.

\begin{tabular}{lcc}
\hline \multicolumn{1}{c}{ Machine/vehicle } & TAR & $\begin{array}{c}e_{\mathrm{W}} \\
(\mathrm{MJ} / \mathrm{kg})\end{array}$ \\
\hline Loaders & $46 \%$ & 7.38 \\
Harvester & $61 \%$ & 13.01 \\
$\begin{array}{l}\text { Trucks, chopper, rectangular } \\
\text { baler, bale processor, shredder }\end{array}$ & $61 \%$ & 14.63 \\
Wagons, telescopic bale grab & $76 \%$ & 7.38 \\
Tractor 31 HP, transport bales & $89 \%$ & 14.63 \\
Windrower & $93 \%$ & 6.28 \\
Tractor 105 HP & $89 \%$ & 14.63 \\
\hline
\end{tabular}

In the case of transportation cost, Eqs. (6)-(8) were adapted; taking into consideration the transport characteristics (USD/t):

$$
C_{R \& M-t r}=\frac{P \cdot T A R}{\gamma \cdot V \cdot h \cdot y}
$$

$C_{f-t r}=\frac{e_{\text {diesel }} \cdot d c \cdot T R_{\text {cycle }}}{V}$

$C_{l-t r}=0.15 \cdot C_{f-t r}$

where $\gamma$ is the number of trips per day. The tons transported per trip $(V)$, is calculated through Eqs. (9) and (10) for tractors and trucks, respectively. $\varphi_{\lambda}$ and $\varphi_{\Lambda}$ are the number of wagons hauled by the tractor or the truck. $\rho_{\mathrm{sc}}$ is the sugarcane density $\left(250 \mathrm{~kg} / \mathrm{m}^{3}\right) . \vartheta_{\lambda}$ and $\vartheta_{\Lambda}$ are the HD8000 and LD24000 wagon volumetric capacity correspondingly. 
$V_{1}=\varphi_{\lambda} \cdot\left(\frac{\rho_{S C} \cdot \vartheta_{\lambda}}{1000}\right)$

$V_{2}=\varphi_{\Lambda} \cdot\left(\frac{\rho_{S C} \cdot \vartheta_{\Lambda}}{1000}\right)$

The transport cycle $\left(\mathrm{TR}_{\text {cycle }}\right)$ in hours is the time of loading, round trip hauling and uploading. An average speed of $30 \mathrm{~km} / \mathrm{h}$ and $35 \mathrm{~km} / \mathrm{h}$ for the full and empty vehicles (trucks and tractors) were assumed [22]. The bales truck (Stinger Stacker) has an average speed of $60 \mathrm{~km} / \mathrm{h}$.

The machinery rates of work were obtained from field studies done by the Colombian Sugarcane Research Center (CENICAÑA) [11]. Additional information related to the cultivation and planting practices were obtained through direct conversation with farmers and experts from the sugarcane industry. All the cost data is related to the situation in August 2012 (1 US\$=1,821 Colombian pesos).

\subsection{Energy Consumption}

Five main components are included in the sugarcane energy consumption: Agricultural inputs, cultivation, harvesting, transport and the construction of machineries. The main agricultural inputs needed for the sugarcane culture are nutrients, pesticides and seeds; and their energy consumption in $\mathrm{MJ} / \mathrm{t}$ is calculated through Eq. (11).

$$
E_{A I}=\sum\left(\frac{\bar{\phi} \cdot E_{p c c}}{S C_{\text {year }}}\right)+E_{\text {her }}+E_{\text {ins }}+E_{s}
$$

where $\bar{\phi}$ is the average annual use of $\mathrm{P}_{2} \mathrm{O}_{5}, \mathrm{~K}_{2} \mathrm{O}, \mathrm{N}$ and lime in $\mathrm{kg} / \mathrm{ha}$-year [32]. For $\mathrm{N}$ requirements, soils with good drainage and more than $4 \%$ of organic matter were assumed [33]. Production energy ratios $\left(E_{\mathrm{pcc}}\right)$ were taken from [34-36] and summarized in Table 3. $\mathrm{SC}_{\text {year }}$ is the sugarcane yield per ha-year. $E_{\mathrm{s}}$ is the energy for seeds assumed to be $2.9 \%$ of the total energy needed for cane production [35]. $E_{\text {her }}$ and $E_{\text {ins }}$ stand for the energy for herbicides and pesticides production, which are $11.26 \mathrm{MJ} / \mathrm{t}$ and $0.79 \mathrm{MJ} / \mathrm{t}$ respectively [35].

Table 3. Agricultural Inputs data.

\begin{tabular}{lccccc}
\hline & \multirow{2}{*}{ Units } & \multicolumn{3}{c}{ Fertilizers } & \multirow{2}{*}{ Lime } \\
\cline { 3 - 5 } & & $\mathrm{N}$ & $\mathrm{P}_{2} \mathrm{O}_{5}$ & $\mathrm{~K}_{2} \mathrm{O}$ & \\
\hline Planting & $\mathrm{kg} / \mathrm{ha}$ & 40 & 11.7 & 52.1 & 250 \\
Each ratoon & $\mathrm{kg} / \mathrm{ha}$ & 75 & 11.7 & 52.1 & 250 \\
$\bar{\phi}$ & $\mathrm{kg} / \mathrm{ha}-\mathrm{year}$ & 340 & 59 & 261 & 1250 \\
$\mathrm{E}_{\mathrm{pcc}}$ & $\mathrm{MJ} / \mathrm{kg}$ & 56.3 & 7.5 & 7.0 & 1.3 \\
\hline
\end{tabular}

The energy needed for cultivation $\left(E_{\mathrm{C}}\right)$ is estimated through Eq. (12) using a mean diesel consumption of 102.6 for planting $\left(E_{\text {planting }}\right)$ and $9.1 \mathrm{l} /$ ha for each ratoon $\left(E_{\text {ratoon }}\right)$ [35]. $S C_{\text {cycle }}$ and $S C_{\text {ha }}$ are the cycles of sugarcane cultivationharvesting; and the sugarcane yield per hectare (117 t/ha).

$E_{C}=\frac{\frac{\left(E_{\text {planting }} \cdot L H V_{\text {diesel }}\right)+\left(4 \cdot E_{\text {ratoon }} \cdot L H V_{\text {diesel }}\right)}{S C_{\text {cycle }}}}{S C_{h a}}$
The energy consumption of the harvesting operations is calculated through Eq. (13), where $\alpha$ is the percentage of cane that is mechanically harvested. In this case, the diesel consumption comes from the harvester use (39.75 1/h) [37]; for the manual harvesting, the fuel consumed by the loader is 10.09 liters/h [34].

$E_{H}=\alpha \cdot S C \cdot\left(\frac{e_{\text {diesel }} \cdot L H V_{\text {diesel }}}{R o W}\right)+(1-\alpha) \cdot S C \cdot\left(\frac{e_{\text {diesel }} \cdot L H V_{\text {diesel }}}{R o W}\right)$

Eq. (14) calculates the energy consumed for transportation in $\mathrm{MJ} / \mathrm{t}$. In the study, $60 \%$ of the cane is transported with tractors towing four wagons and the rest is transported with trucks hauling two wagons [37].

$E_{T R}=\hat{e}_{\text {diesel }} \cdot L H V_{\text {diesel }} \cdot d$

Where $\hat{e}_{\text {diesel }}$ is the diesel consumption $(1 / \mathrm{t}-\mathrm{km})$ and $\mathrm{d}$ is the transportation distance in $\mathrm{km}$. The energy used for the machinery/vehicle maintenance $(\mathrm{MJ} / \mathrm{t})$ is calculated using Eq. (15). To calculate the energy needed for the repaired parts and maintenance, a machinery reliable life of $82 \%$ of the total life is assumed [31].

$$
E_{M M}=\frac{[(E E+M E) \cdot 0.82]+E_{R \& M}}{h \cdot R o W \cdot y}
$$

where $E E$ is the embodied energy from the raw materials and is calculated using the machinery weight $\left(W_{\text {steel }}\right)$ and the percentage of weight equivalent to the tires $\left(W_{\text {tires }}\right)$. Then, the machinery weight is multiplied by the embodied energy coefficient $(62.80 \mathrm{MJ} / \mathrm{kg}$ for the steel and $85.83 \mathrm{MJ} / \mathrm{kg}$ for the tires) $E E=85.83 \cdot W_{\text {tires }}+62.80 \cdot W_{\text {steel }}$. The amount of energy needed for the equipment manufacturing is calculated using $M E=e_{W}\left(W_{\text {steel }}+W_{\text {tires }}\right)$ on the basis of the machinery weight and the coefficient appropriated for its class (Table 2) [31]. $E_{R \& M}$ is the energy from repair parts and materials that would be applied to a piece of machinery over its useful life, and is calculated using $E_{R \& M}=[T A R \cdot(E E+M E)] / 3[31]$. The total energy consumption $(\mathrm{MJ} / \mathrm{t})$ at the mill gate is then the sum of all the components mentioned before. The energy consumption for the GHR supply considers the energy for the collection, processing, transport and the machinery/vehicle manufacturing.

\subsection{Life Cycle GHG Emissions}

The life cycle GHG emission analysis follows the standard LCA methodology, ISO 2006, for the system boundary shown in Figure 1 and for the functional unit of one dry-ton of GHR. It includes the collection, transportation, and treatment of GHR from the field to the gate of the plant for the three strategies. The GHR is an agricultural waste; therefore, the agricultural inputs such as seeds, fertilizers, etc. are allocated to sugarcane production. 
Table 4. Biomass Throughput and Supply Cost.

\begin{tabular}{|c|c|c|c|c|}
\hline & \multirow{2}{*}{ Unit } & \multicolumn{3}{|c|}{ Strategy } \\
\hline & & Chopped & Baled & Integral \\
\hline Sugarcane delivered & t/day & $13^{\prime} 000$ & $13^{\prime} 000$ & $13^{\prime} 000$ \\
\hline GHR moisture & $\%$ & 12 & 15 & 38 \\
\hline GHR density & $\mathrm{kg} / \mathrm{m}^{3}$ & 90 & 223 & 270 \\
\hline Sugarcane Harvesting & $\mathrm{US} \$ / \mathrm{t}$ & $1.06-6.30$ & $1.06-6.30$ & $1.06-6.30$ \\
\hline Sugarcane loading & $\mathrm{US \$ t}$ & 0.13 & 0.13 & 0.26 \\
\hline Sugarcane transport & $\mathrm{US} \$ / \mathrm{t}-\mathrm{km}$ & $0.88-1.11$ & $0.88-1.11$ & $0.87-1.10$ \\
\hline GHR Windrowing & $\mathrm{US} \$ / \mathrm{t}$ & 0.45 & 0.45 & - \\
\hline GHR bale breaking & $\mathrm{US} \$ / \mathrm{t}$ & - & 1.84 & - \\
\hline GHR transport & $\mathrm{US} \$ / \mathrm{t}-\mathrm{km}$ & $5.62-6.58$ & 6.96 & $1.83-2.18$ \\
\hline Sugarcane cost & $\mathrm{US} \$ / \mathrm{t}$ & 30.59 & 30.59 & 30.95 \\
\hline GHR cost & US\$/dry-t & 16.84 & 18.63 & 6.01 \\
\hline
\end{tabular}

The Intergovernmental Panel on Climate Change (IPCC) 2007 emission factors of 1 for $\mathrm{CO}_{2}, 25$ for $\mathrm{CH}_{4}$, and 298 for $\mathrm{N}_{2} \mathrm{O}$ :http://www.ipcc.ch/publications_and_data/ar4/wg1/en/ch2 s2-102.htm, for a time horizon of 100 years are used to estimate the total $\mathrm{GHG}$ emissions on the basis of $\mathrm{kg} \mathrm{CO}_{2}$ equivalent (eq) per functional unit following Eq. (16).

$$
E M=\sum Q_{i} \cdot E F_{i}
$$

Where, $Q$ is the quantity of gas substance $i$ in $\mathrm{kg}$ of gas per functional unit of the operation (e.g. $\mathrm{kg} \mathrm{CH}_{4} / \mathrm{kWh}$ ) and $E F$ is the emission factor of substance gas $i$ (e.g. 25 for $\mathrm{CH}_{4}$ ).

The study has used the National Renewable Energy Laboratory (NREL) datasets (http://www.nrel.gov/lci/) for the analysis of $\mathrm{CO}_{2}$ equivalent emissions of the activities involved in GHR supply. Even though the bagasse could be used to provide energy through cogeneration processes (Selling the surplus power to the national electric grid); no all the sugar mills have it and then trade the bagasse with the paper industry. Due to this, it is assumed that the power for cleaning, shredding and bale processing will be supplied form the Colombian national power grid with $\mathrm{CO}_{2}$ emissions of $0.285 \mathrm{~kg} \mathrm{CO}_{2} / \mathrm{kWh}$ (CDM, 2012).

The environmental load of the mobile and stationary operations is the summation of the calculated $\mathrm{CO}_{2}$ equivalent emissions through the following equations:

$$
\begin{aligned}
& E L_{e c}=\text { electricity } \cdot E M_{\text {rem }} \\
& E L_{d c}=\frac{\text { diesel } \cdot E M_{\text {database }} \cdot G H R_{\text {wet }} \cdot T R_{\text {cycle }}}{\text { diesel }_{\text {database }} \cdot G H R_{d r y}} \\
& E L_{s d c}=\text { diesel } \cdot E M_{\text {database }} \\
& G H G E=E L_{e c}+E L_{m d c}+E L_{s d c}
\end{aligned}
$$

where, $E L$ is the environmental load of each operation in $\mathrm{kg}$ $\mathrm{CO}_{2}$ equivalent per GHR dry-t; $E M$ is the emissions of $\mathrm{kg}$ $\mathrm{CO}_{2}$ equivalent per functional unit of each operation (e.g. $\mathrm{kg}$
$\mathrm{CO}_{2} \mathrm{eq} / \mathrm{kWh}$ electricity from mix grid), and GHGE is the total greenhouse gas emissions of the logistics operation in $\mathrm{kg} \mathrm{CO} 2$ eq/dry-t GHR.

\section{Results and Discussion}

The methodology was implemented using a representative sugar mill as a case study. The lignocellulosic ethanol plant will be located adjacent to the sugar mill in order to take advantage of the current milling capacity of $13^{\prime} 000$ cane tons per day. The gross area of 45'199 hectares is available, where $38^{\prime}, 902$ hectares are planted with sugarcane.

Table 4 presents the results of calculated supply cost for each strategy. In the case of the pull-type equipment, the cost was charged to the tractor. For the evaluation of the sugarcane cultivation, the cost is provided by the Colombian association of sugarcane producers and suppliers (PROCAÑA). Cultivation costs include direct and administrative costs for the ratoon and renovation activities. The cultivation cost accounts for $69 \%$ of the sugarcane cost at mill-gate. The integral harvesting strategy has an extra cost of $20 \%$ approximately due to the additional application of chemical fertilizers for the absence of GHR nutrients in the field. Transportation represents $7 \%$ of the supply cost at millgate.

Table 4, highlights that the collection and processing activities represent $9.74,9.24$ and $1.22 \mathrm{USD} / \mathrm{t}$ of the total GHR supply cost for the chopped, baled and the integral harvesting, respectively. The transportation cost represents $42 \%$ and $50 \%$ of the total cost for the chopped and baled GHR, whereas it has a significant value of $80 \%$ of the total cost for the integral harvesting with the lowest GHR supply cost.

In the case of the sugarcane supply, there is an increment of $0.36 \mathrm{USD}$ per ton at the mill-gate under integral harvesting. The main reason is partially due to the use of extra fertilizers to compensate for the nutrition of the removed GHR and also due to the high quantity of the loaded biomass. Table 5 summaries the energy consumption for the three strategies. 


\begin{tabular}{|c|c|c|c|c|}
\hline & \multirow{2}{*}{ Unit } & \multicolumn{3}{|c|}{ Strategy } \\
\hline & & Chopped & Baled & Integral \\
\hline Cultivation & $\mathrm{MJ} / \mathrm{t}$ & 8.65 & 8.65 & 8.65 \\
\hline Harvesting & $\mathrm{MJ} / \mathrm{t}$ & 17.36 & 17.36 & 17.36 \\
\hline Sugarcane loading & $\mathrm{MJ} / \mathrm{t}$ & 2.05 & 2.05 & 2.93 \\
\hline \multicolumn{5}{|l|}{ Sugarcane transport } \\
\hline Tractor & $\mathrm{MJ} / \mathrm{t}-\mathrm{km}$ & 0.50 & 0.50 & 0.50 \\
\hline Truck & $\mathrm{MJ} / \mathrm{t}-\mathrm{km}$ & 0.70 & 0.70 & 0.70 \\
\hline \multicolumn{5}{|l|}{ Agricultural inputs for sugarcane } \\
\hline Fertilizers \& lime & $\mathrm{MJ} / \mathrm{t}$ & 36.80 & 36.80 & 41.96 \\
\hline Pesticides \& herbicides & $\mathrm{MJ} / \mathrm{t}$ & 7.18 & 7.18 & 7.18 \\
\hline Seeds* & $\mathrm{MJ} / \mathrm{t}$ & 3.15 & 3.15 & 3.33 \\
\hline Machinery & $\mathrm{MJ} / \mathrm{t}$ & 10.55 & 10.55 & 12.05 \\
\hline Windrowing & $\mathrm{MJ} / \mathrm{t}$ & 9.86 & 9.86 & - \\
\hline Chopping & $\mathrm{MJ} / \mathrm{t}$ & 71.74 & - & - \\
\hline Baling & $\mathrm{MJ} / \mathrm{t}$ & - & 38.54 & - \\
\hline GHR loading/unloading & $\mathrm{MJ} / \mathrm{t}$ & - & 11.94 & 2.93 \\
\hline GHR transport & $\mathrm{MJ} / \mathrm{t}-\mathrm{km}$ & $1.49-2.11$ & 3.61 & - \\
\hline Bale breaker & $\mathrm{MJ} / \mathrm{t}$ & - & 26.40 & - \\
\hline Cane cleaning & $\mathrm{MJ} / \mathrm{t}$ & - & - & 3.28 \\
\hline Machinery & $\mathrm{MJ} / \mathrm{t}$ & 8.76 & 10.41 & 20.57 \\
\hline Sugarcane energy consumption & $\mathrm{MJ} / \mathrm{t}$ & 108.71 & 108.71 & 116.46 \\
\hline GHR energy consumption & $\mathrm{MJ} / \mathrm{dry}-\mathrm{t}$ & 172.16 & 258.65 & 125.32 \\
\hline Lignocelullosic ethanol production & liters/day & 417,648 & 389,805 & 539,886 \\
\hline Energy equivalence & MJ/day & $8,786,473$ & $8,200,708$ & $11,358,124$ \\
\hline Market price & US\$/day & 384,653 & 359,010 & 497,235 \\
\hline
\end{tabular}

$*$ A piece of cane stalk is used as seed to generate the next ratoon.

The chopped GHR has the highest energy consumption for collection and processing $(120 \mathrm{MJ} / \mathrm{t})$, followed by baling $(117 \mathrm{MJ} / \mathrm{t})$ and integral harvesting $(64 \mathrm{MJ} / \mathrm{t})$. The transport represents $30 \%, 55 \%$ and $49 \%$ of the total energy consumed for the three strategies, respectively.

In the case of the sugarcane supply, the energy from the operations (cultivation, harvesting and transport) represents $41 \%$ of the total energy consumed, where the transport absorbs $21 \%$. The agricultural inputs contribute to the total energy consumption by $43 \%$ with a $2 \%$ increment when integral harvesting is used. Table 5 also shows the expected amount of GHR-based lignocellulosic ethanol production and its fuel value. The same ethanol yield of 340 liters per dry-t from corn stover was assumed for the GHR due to the similar composition of both biomasses [6].

The results in Figure 2 indicate that the supply using integral harvesting emits considerably less GHG emissions by $57 \%$ and $84 \%$ compared to the first and second strategies. This advantage is mainly due to the fact that in the integral harvesting a higher quantity of the GHR can be collected and transported to the plant, and the fuel consumption for the cultivation and harvesting process is totally allocated to the sugarcane.

However, one important drawback is that in the integrated harvesting less proportion of GHR is left on the soil, therefore, the consequent nutrient deficiency should be compensated from other sources. Evidently, implementing of the chemical fertilizers would create additional GHG emissions for the third strategy. Taking into account this negative point, the overall GHG emissions of this strategy would increase to $9.54 \mathrm{~kg} \mathrm{CO}$-eq/GHR dry-t which is still favorable compared to the other two strategies. Another alternative is to recycle the sludge or wastewater produced in the bioethanol plant to the field which could be considered as an environmental friendly substitution. Due to the data uncertainty, this alternative has not been considered.

\section{Conclusions}

The paper analyzed the techno-economic and environmental assessment of sugarcane and green harvesting residues in the sugar-ethanol supply chain. Three different strategies to supply the sugarcane to the mill and the GHR to the lignocellulosic biorefinery were studied calculating the amount of biomass delivered, logistic cost, energy consumption and GHG emissions. The daily liters of lignocellulosic ethanol were also calculated. The integral harvesting showed the best performance in costs (6.01 USD/dry-t), energy consumptions (125.32 MJ/dry-t), and GHG emissions (7.74 $\mathrm{kg} \mathrm{CO}$-eq/dry-t), followed by the baled and chopped strategies. A potential lignocellulosic ethanol production of 539,886 liter per day could be reached under the integral harvesting.

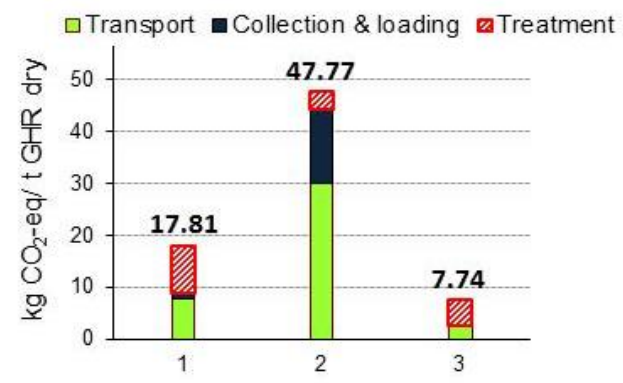

Figure 2. GHG emissions of the three GHR logistics strategies. 


\begin{tabular}{|c|c|}
\hline \multicolumn{2}{|c|}{ Nomenclature } \\
\hline$d$ & travel distance, $\mathrm{km}$ \\
\hline$d c$ & fuel cost, USD/1 \\
\hline$C$ & variable cost, USD/t \\
\hline E & energy consumption, $\mathrm{MJ} / \mathrm{t}$ \\
\hline$E E$ & embodied energy from the raw materials, $\mathrm{MJ} / \mathrm{t}$ \\
\hline $\mathrm{EF}$ & emission factor of gas substance, unit-less \\
\hline EL & $\begin{array}{l}\text { environmental load for each operation, } \mathrm{kg} \mathrm{CO}_{2} \text {-eq/ } \\
\text { GHR dry-t }\end{array}$ \\
\hline EM & $\begin{array}{l}\text { Emissions per functional unit of each operation, } \mathrm{kg} \\
\mathrm{CO}_{2} \text {-eq/kWh or } \mathrm{kg} \mathrm{CO} \text {-eq/t-km or } \mathrm{kg} \mathrm{CO} \mathrm{CO}_{2}-\mathrm{eq} / \mathrm{l}\end{array}$ \\
\hline$\hat{e}$ & diesel consumption, $1 / \mathrm{t}-\mathrm{km}$ \\
\hline$e$ & diesel consumption, $1 / \mathrm{h}$ \\
\hline$G H R$ & green harvesting residues, dry-t \\
\hline$G H G$ & greenhouse gas, $\mathrm{kg} \mathrm{CO}_{2}$-eq \\
\hline $\mathrm{GHG}$ & $\begin{array}{l}\text { total greenhouse gas emissions, in } \mathrm{kg} \mathrm{CO}_{2} \mathrm{eq} / \mathrm{GHR} \\
\text { dry-t }\end{array}$ \\
\hline$h$ & annual working hours, $\mathrm{h} /$ year \\
\hline$i$ & discount rate \\
\hline$K$ & fix cost, USD \\
\hline$L H V$ & lower heating value, $\mathrm{MJ} / \mathrm{kg}$ \\
\hline$M E$ & $\begin{array}{l}\text { energy needed for the equipment manufacturing, } \\
\mathrm{MJ} / \mathrm{t}\end{array}$ \\
\hline$P$ & purchase price, USD \\
\hline Q & $\begin{array}{l}\text { quantity of substance, } \mathrm{kg} \text { per functional unit of the } \\
\text { operation }\end{array}$ \\
\hline RoW & rate of work, $\mathrm{t} / \mathrm{h}$ \\
\hline$S C$ & sugarcane \\
\hline$T A R$ & total accumulated repair factor, $\%$ \\
\hline$V$ & amount of tons transported per trip, $t /$ trip \\
\hline$y$ & lifetime, years \\
\hline \multicolumn{2}{|c|}{ Greek symbols } \\
\hline$\alpha$ & percentage of cane that is mechanically harvested \\
\hline$\gamma$ & vehicle trips per day \\
\hline$\varphi$ & number of wagons \\
\hline$\lambda$ & tractor \\
\hline$\Lambda$ & truck \\
\hline$\rho$ & density, $\mathrm{kg} / \mathrm{m}^{3}$ \\
\hline$\vartheta$ & wagon volumetric capacity, $\mathrm{m}^{3}$ \\
\hline $\bar{\phi}$ & $\begin{array}{l}\text { average annual use of agricultural inputs, } \mathrm{kg} / \mathrm{ha} \text { - } \\
\text { year }\end{array}$ \\
\hline
\end{tabular}

\section{Subscripts and superscripts}

agr agricultural operations

AI agricultural inputs

c cultivation

dc diesel consumption

ec electricity consumption

f fuel

$\mathrm{H} \quad$ harvesting

ha hectare

her herbicides

i Substance gases i $\left(\mathrm{CO}_{2}, \mathrm{~N}_{2} \mathrm{O}\right.$ and $\left.\mathrm{CH}_{4}\right)$

$\begin{array}{ll}\text { ins } & \text { insecticides } \\ 1 & \text { lubricants } \\ \text { MM } & \text { maintenance and spare parts } \\ \text { pcc } & \text { production } \\ \text { rem } & \text { regional electricity mix } \\ \text { R\&M } & \text { repairs and maintenance } \\ \text { s } & \text { seeds } \\ \text { sdc } & \text { stationary diesel consumption } \\ \text { t } & \text { taxes, insurance and storage } \\ \text { TR/tr } & \text { transport }\end{array}$

\section{References}

[1] A. Ajanovic, Biofuels versus food production: Does biofuels production increase food prices?, Energy 36, 2070-2076, 2011.

[2] M. O. Dias, T. L. Junqueira, C. R. C. Jesus, R. M. Filho y A. Bonomi, Improving second generation ethanol production through optimization of first generation production process from sugarcane, Energy. 43, 246-252, 2012.

[3] IEA Bioenergy, Gaps in the research of 2nd generation transportation biofuels. Energy Systems Analysis, 17 December 2009. [Online]. Available: http://www.iea.org/publications/freepublications/publica tion/2nd_Biofuel_Gen.pdf.

[4] A. Méjean y C. Hope, Modeling the costs os energy crops: A case study of US corn and Brazilian sugarcane, Energy policy 38, 547-561, 2010.

[5] J. Allen, M. Browne, A. Hunter, J. Boyd y H. Palmer, Logistics management and costs of biomass fuel supply, International Journal of Physical Distribution \& Logistics Management 28, 463-477, 1998.

[6] NREL, Lignocellulosic Biomass to Ethanol Process Design and Economics Utilizing Co-Current Dilute Acid Prehydrolysis and Enzymatic Hydrolysis for Corn Stover, NREL, Golden Colorado, 2002.

[7] IEA, World Energy outlook 2010, OECD/International Energy Agency, Paris, 2010.

[8] L. G. Amú, Optimization model for allocating transport and harvesting equipment within a sugarcane supply system (In Spanish), VIII Congreso de la Asociación Colombiana de Técnicos de la Caña de Azúcar, 2009.

[9] Centro Nacional de Productividad, The Cauca Valley sugar conglomerate, Colombia (In Spanish), Natural resources clusters, Santiago de Chile, United Nations ISSN: 1680-8754, 47, 2002.

[10] S. Gaucher, P.-Y. Gal y G. Soler, Modelling supply chain management in the sugar industry, Proc $S$ Afr Sug Technol Assis. 77, 542 - 554, 2003.

[11] J. S. Torres y F. Villegas, Management and use of crop residues in Green harvesting (In Spanish), In CENICAÑA: Crop management for green cane harvesting, Cali, 82 - 165, 2006 
[12] J. I. Victoria, A. Durán, C. Posada, J. Gómez y J. M. Pinzón, Sugarcane varieties evaluation for mechanical green harvesting (In Spanish), In: CENICAÑA: Crop management for green harvesting, Cali, Serie Técnica No. 35, 2006.

[13] I. Dukulis, G. Birzietis y D. Kanaska, Optimization models for biofuel logistic systems, Jelgava: Latvia University of Agriculture, 2008.

[14] M. Delivand, M. Barz y S. Gheewala, Logistics cost analysis of rice straw for biomass power generation in Thailand, Energy 36, 1435-1441, 2011.

[15] S. Sokhansanj, A. Turhollow y E. Wilkerson, Development of the Integrated Biomass Supply Analysis and Logistics Model (IBSAL), Oak Ridge National Laboratory, Tennessee, 2008.

[16] E. Thuijl, R. Ree y T. Lange, Biofuel production chains. Background document for modelling the EU biofuel market using the BIOTRANS model (ECN-C--03-088), ECN Policy Studies, 2003.

[17] M. Michelazzo y O. Braunbeck, Analysis of six trash collection systems in mechanical harvesting of sugarcane (In Portuguese), Revista brasileira de Engenharia Agrícola e Ambiental. 12, 546 - 552, 2008.

[18] T. C. Ripoli y M. L. Ripoli, Advantages of using sugarcane trash for burning and steam production (In Spanish), TECNICAÑA 21, 22- 25, 2009.

[19] C. O. Briceno, J. H. Cock y J. Torres, Electric power from green harvesting residues of sugar cane in Colombia: A Pre-Feasibility Study on its Technical and Economic Viability, International Sugar Journal 103, 107 - 111, 2001.

[20] E. Searcy y P. Flynn, The Impact of Biomass Availability and Processing Cost on Optimum Size and Processing Technology Selection, Appl Biochem Biotechnol 154, 271 - 286, 2009.

[21] IEA Bioenergy, from 1st-to 2nd-generation biofuel technologies: An overview of current industry, Paris: OECD/IEA, 2008.

[22] L. G. Amú, Methodology for the implementation of a system for collecting and transporting sugarcane green harvesting residues to generate electricity (In Spanish), Cali: Universidad del Valle, 2003.

[23] O. Braunbeck, A. Bauen, F. Rosillo-Calle y L. Cortez, Prospects for green cane harvesting and cane residue use in Brazil, Biomass and Bioenergy 17, 495 - 506, 1999.

[24] S. J. Hassuani, M. R. L. Verde y I. Macedo, Biomass power generation: sugar cane bagasse and trash, Piracicaba: PNUD-CTC, 2005.

[25] J. Carbonell González, R. Quintero Durán, J. Torres Aguas, C. Osorio Murillo, C. Isaacs Echeverri y J. Victoria Kafure, Agro-ecological zoning for growing sugarcane in the Cauca River Valley (Fourth version): Methodological principles and applications (In Spanish), Cali: Cenicaña. 119 p. (Serie Técnica No. 38), 2011.

[26] S. Sokhansanj y A. Turhollow, Baseline cost for corn stover collection, Applied Engineering in Agriculture 18, 525 - 530, 2002.
[27] BNDES y CGEE, Bioethanol from sugarcane: Energy for the sustainable development (In Portuguese), ISBN: 97885-87545-24-4, Rio de Janeiro, 2008.

[28] IEA, Biofuels for Transport: An International Perspective, 2004. [Online]. Available: http://www.iea.org/publications/free_new_Desc.asp?PU BS_ID=1262.

[29] R. D. Perlack, L. L. Wright, A. F. Turhollow, R. L. Graham, B. J. Stokes y D. C. Erbach, Biomass as Feedstock for a Bioenergy and Bioproducts Industry: The Technical Feasibility of a Billion-Ton Annual Supply, U.S. Department of Energy GO-102005-2135, 2005.

[30] J. R. Hess, C. T. Wright y K. L. Kenney, Cellulosic biomass feedstocks and logistics for ethanol production, Biofuels Bioproducts \& Biorefining 1, 181-190, 2007.

[31] D. Pimentel, Handbook of energy utilization in agriculture, Florida: CRC press, Inc., 1980.

[32] Consorcio CUE, Sustainable energy and biofuels strategies for Colombia ATN/JC-10826-CO and ATN/JF-10827-CO (In Spanish), Inter-American Development Bank (IDB) - Mining and Energy Ministry, Medellin, 2012.

[33] R. Quintero, Fertilization and nutrition (In Spanish), In CENICAÑA: Sugarcane harvesting in Colombia, Cali, CENICAÑA, 1995, 153-177.

[34] I. Macedo, M. Lima y J. Azevedo, Balance of greenhouse gases emissions in the production and use of ethanol in Brazil (In Portuguese), Governo do Estado do São Paulo, São Paulo, 2004.

[35] I. Macedo, J. Seabra y J. Silva, Green house gases emissions in the production and use of ethanol from sugarcane in Brazil: The 2005/2006 averages and a prediction for 2020, Biomass and bioenergy 32, 582 595, 2008.

[36] T. Nemecek y T. Kägi, Life cycle inventories of Swiss and European agricultural production systems. Final report ecoinvent V2.0 No. 15a., Agroscope ReckenholzTaenikon research station ART, Swiss Centre for Life Cycle Inventories, Zurich \& Dübendorf, 2007.

[37] J. S. Torres y C. A. Madriñan, Equipment and labor for green harvesting (In Spanish). In CENICAÑA: Crop management for green cane harvesting, Cali, CENICAÑA, 2006, 165. 